Article

\title{
Cytotoxicity of Essential Oil Cordia verbenaceae against Leishmania brasiliensis and Trypanosoma cruzi
}

\author{
Pedro S. Pereira ${ }^{1}{ }^{(}$, , Carlos Vinicius B. Oliveira ${ }^{1}\left(\mathbb{D}\right.$, Ana J. Maia ${ }^{1}$, Saulo R. Tintino ${ }^{2}$, \\ Cícera Datiane de M. Oliveira-Tintino ${ }^{2}$, Maria C. Vega-Gomez ${ }^{2}$, Miriam Rolón ${ }^{2}$, Cathia Coronel ${ }^{2}$, \\ Antônia Eliene Duarte ${ }^{1}$, Luiz M. Barros ${ }^{1}$, Jeam Paul Kamdem ${ }^{1}{ }^{10}$, Abolghasem Siyadatpanah ${ }^{3}$, \\ Polrat Wilairatana ${ }^{4, *(1)}$ and Henrique D. M. Coutinho ${ }^{5, *}$ (C)
}

1 Laboratório de Farmacologia e Química Molecular, Universidade Regional do Cariri, Rua Cel. Antonio Luis 1161, Pimenta, Crato 63105-000, Brazil; pedro.sillvino@gmail.com (P.S.P.); viniciusbluesky@gmail.com (C.V.B.O.); anajosicleide.maia@gmail.com (A.J.M.); duarte105@yahoo.com.br (A.E.D.); Imarivando@gmail.com (L.M.B.); kamdemjeanpaul2005@yahoo.fr (J.P.K.)

2 Centro para el Desarrollo de la Investigación Científica (CEDIC), Fundación Moisés Bertoni/Laboratorios Díaz Gill., Asunción 1255, Paraguay; saulorelison@gmail.com (S.R.T.);

datianemorais@gmail.com (C.D.d.M.O.-T.); mcvegagomez@gmail.com (M.C.V.-G.); rolonmiriam@gmail.com (M.R.); cathiacoronel@gmail.com (C.C.)

check for updates

Citation: Pereira, P.S.; Oliveira, C.V.B.; Maia, A.J.; Tintino, S.R.; Oliveira-Tintino, C.D.d.M.; Vega-Gomez, M.C.; Rolón, M.; Coronel, C.; Duarte, A.E.; Barros, L.M.; et al. Cytotoxicity of Essential Oil Cordia verbenaceae against Leishmania brasiliensis and Trypanosoma cruzi. Molecules 2021, 26, 4485. https://doi.org/10.3390/ molecules26154485

Academic Editors: Francesca

Mancianti and Valentina

Virginia Ebani

Received: 26 June 2021

Accepted: 23 July 2021

Published: 25 July 2021

Publisher's Note: MDPI stays neutral with regard to jurisdictional claims in published maps and institutional affiliations.

Copyright: (C) 2021 by the authors Licensee MDPI, Basel, Switzerland. This article is an open access article distributed under the terms and conditions of the Creative Commons Attribution (CC BY) license (https:// creativecommons.org/licenses/by/ $4.0 /)$.
3 Ferdows School of Paramedical and Health, Birjand University of Medical Sciences, Birjand 9717853577, Iran; asiyadatpanah@yahoo.com

4 Department of Clinical Tropical Medicine, Faculty of Tropical Medicine, Mahidol University, Bangkok 10400, Thailand

5 Laboratório de Microbiologia e Biologia Molecular, Universidade Regional do Cariri, Rua Cel. Antonio Luis 1161, Pimenta, Crato 63105-000, Brazil

* Correspondence: polrat.wil@mahidol.ac.th (P.W.); hdmcoutinho@gmail.com (H.D.M.C.)

\begin{abstract}
The species Cordia verbenacea DC (Boraginaceae), known as the whaling herb and camaradinha, is a perennial shrub species native to the Atlantic Forest. Its leaves are used in folk medicine as an anti-inflammatory, analgesic, antiulcerogenic and curative agent, in the form of teas or infusions for internal or topical use. The present study aimed to verify the cytotoxicity of the essential oil and the leishmanicidal and trypanocidal potential of $C$. verbenacea. The essential oil was characterized by GC-MS. The in vitro biological activity was determined by anti-Leishmania and anti-Trypanosoma assays. The cytotoxixity was determined using mammalian fibroblasts. The $C$. verbenacea species presented $\alpha$-pinene (45.71\%), $\beta$-caryophyllene (18.77\%), tricyclo[2,2,1-(2.6)]heptane $(12.56 \%)$ as their main compounds. The essential oil exhibited strong cytotoxicity at concentrations below $250 \mu \mathrm{g} / \mathrm{mL}$ $\left(\mathrm{LC}_{50} 138.1 \mu \mathrm{g} / \mathrm{mL}\right.$ ) in mammalian fibroblasts. The potent anti-trypanosome and anti-promastigote activities occurred from the concentration of $62.5 \mu \mathrm{g} / \mathrm{mL}$ and was considered clinically relevant. The results also demonstrate that at low concentrations $(<62.5 \mu \mathrm{g} / \mathrm{mL})$, the essential oil of $C$. verbenacea managed to be lethal for these activities. This can be considered an indication of the power used in daily human consumption. Therefore, it can be concluded that the essential oil of $C$. verbenacea contains a compound with remarkable antiparasitic activities and requires further research.
\end{abstract}

Keywords: anti-kinetoplastidea; alfa-pinene; caryophyllene; tricyclo[2.2.1-(2,6)]heptane; Chagas disease; essential oil; natural product

\section{Introduction}

Parasitic diseases are among some of the most devastating and prevalent infections, causing millions of morbidities and deaths annually, where one of the main causes are kinetoplastids [1]. The kinetoplastid class is a diverse group of single-celled flagellate organisms, many of which are human parasites, that commonly present a reduction in or total elimination of biochemical pathways that can be augmented or provided by their hosts [2,3]. Diseases ignored by parasites such as Leishmania brasiliensis and Trypanosoma 
cruzi (kinetoplastids) affect thousands of people worldwide, and so there is an ongoing effort to identify new chemotherapies $[4,5]$.

Viable antileishmanial drugs still depend on high doses of pentavalent antimonials, such as glucantime and meglumine antimoniate, that cause severe side effects and require long-term treatment [6]. Pentavalent antimonials are rapidly absorbed after administration and are converted into trivalent antimonite, the active form of the drug, which occurs either in the macrophages or in the parasite [7-9]. A specific parasite enzyme (thiol-dependent reductase I-TDR1) is capable of catalyzing the conversion of the pentavalent form of antimony to the trivalent one using glutathione as the reducing agent $[10,11]$. The active mechanism of antimonials is based on the interference of amastigote bioenergetic processes, involved in glycolysis and fatty acid oxidation, and reports have raised the possibility that antimony could trigger apoptosis [12]. Recently, a variety of enzymes have become targets for the development of new therapies against leishimaniasis, such as: ornithine decarboxylase (ODC), dihydrofolate reductase (DHFR), thymidylate synthase (TS) and trypanothione reductase [13-15].

There are currently only two anti-trypanosome drugs marketed: nifurtimox $\left(\mathrm{Lampit}^{\circledR}\right.$, Bayer, Leverkusen, Germany), 3-methyl-4-(5'-nitrofurfurilideneamino) tetrahydro-4H-1,4thiazine-1,1-dioxide; and benznidazole (Rochagan ${ }^{\circledR}$, Roche, Basel, Switzerland), N-benzyl2-nitroimidazole acetamide $[16,17]$. However, both drugs can have numerous side effects in adults, in addition to inducing resistance in microorganisms [18]. The most common side effects in treatment with nifurtimox are nausea, vomiting, epigastric pain and dysphagia. Adverse events that occur most frequently in treatment with benzonidazole are itching, rash and sensitive neuropathy $[19,20]$. Among the compounds found in plants, alkaloids, flavonoids, piperine, terpenes and naphthoquinones represent important classes of natural products that have been tested [21].

In this context, essential oils from various plant species have become potential chemotherapeutic agents due to their antiparasitic properties [22-24]. Essential oils are insoluble in inorganic solvents (water), while also soluble in organic solvents. They are volatile liquids, with a characteristic odor, generally present in medicinal plants and composed of a mixture of substances of different classes [25-27]. Essential oils are of increasing importance in pharmaceutical practices due to their wide range of applications and biological activities [28,29]. Among the numerous pharmacological properties of essential oils are: antimicrobial [30], antiparasitic [31,32], antiulcerogenic [33], insecticide [34] and antifungal [35] properties. They are also widely used in perfumery, aromatherapy and added to spices or herbs [36,37]. The antileishimanial and antiprypanosomal activity of essential oils acts mainly by inducing apoptosis and damaging the only mitochondria of microorganisms, respectively $[38,39]$.

From this perspective, a species whose essential oil has a huge medicinal potential is C. verbenaceae DC (Family: Boraginaceae. Synonyms: Varronia curissavica Jacq., Cordia curassavica (Jacq.) Roem. \& Schult. and Cordia monosperma Jacq. which has been used in the treatment of bladder diseases), a perennial plant commonly found throughout the Brazilian coast [40] and commonly known as "erva baleeira". It is a medicinal herbaceous dicocotyledonous plant not endemic in Brazil. Its globular trichomes are characterized by the secretion of a terpenoid essential oil, while in reniforms it contains mainly phenolic compounds, such as flavonoids [41,42].

The $\alpha$-pinene, $\alpha$-santalene and (E)-cariophyllene are the representative compounds present in the essential oil of $C$. verbenaceae $[43,44]$. The economic and pharmacological potential of this essential oil is due to the production of the chemical markers $\beta$-caryophyllene and $\alpha$-humulene [40], which are associated with cytotoxicity and antiproliferative, proapoptotic and antitumor activities [45].

The study of $C$. verbenaceae in this research is due to its wide popular use and several biological activities mentioned above. The present study aimed to verify the leishmanicidal and trypanocidal power, as well as the cytotoxicity in vitro of the $C$. verbenaceae essential oil. 


\section{Results}

According to Table 1, the chemical composition of the C. verbenaceae essential oil presented $\alpha$-cymene, Caryophyllene and Tricyclo[2.2.1.0(2,6)]heptane as the major constituents, followed by other compounds at lower concentrations.

Table 1. Chemical composition (\%) of the essential oil of C. verbenacea.

\begin{tabular}{|c|c|c|}
\hline Components & $\mathrm{RT}(\min )^{a}$ & $(\%)$ \\
\hline$\alpha$-thujene & 12.09 & 1.70 \\
\hline$\alpha$-pinene & 12.52 & 45.71 \\
\hline Zingiberene & 39.91 & 1.37 \\
\hline Tricyclo[2.2.1.0(2,6)]heptane & 40.90 & 12.56 \\
\hline Caryophyllene & 41.13 & 18.77 \\
\hline$\alpha$-humulene & 43.24 & 3.43 \\
\hline Alloaromadendrene & 43.77 & 4.37 \\
\hline Beta-bisabolene & 46.10 & 3.53 \\
\hline Tetradecane & 47.86 & 1.19 \\
\hline Nerolidol & 52.70 & 3.38 \\
\hline Caryophyllene oxide & 47.98 & 2.04 \\
\hline$\alpha$-sinensal & 49.04 & 2.43 \\
\hline Santalol & 49.15 & 2.90 \\
\hline Total & & 100.00 \\
\hline
\end{tabular}

Averages followed by different letters differ by Tukey test at $p<0.05{ }^{\text {a }}$ Retention time.

The cytotoxic activity had an $\mathrm{LC}_{50}$ of $138.1 \mu \mathrm{g} / \mathrm{mL}$ (Figure 1 and Table 2). According to Figures 2 and 3, and Tables 3 and 4, the essential oil of C. verbenaceae exhibited values considered relevant for the promastigote and epimastigote forms of L. brasiliense and $T$. cruzi, with $\mathrm{LC}_{50}$ values of $67.18 \mu \mathrm{g} / \mathrm{mL}$ for Leishmania and $92.01 \mu \mathrm{g} / \mathrm{mL}$ for Trypanosome.

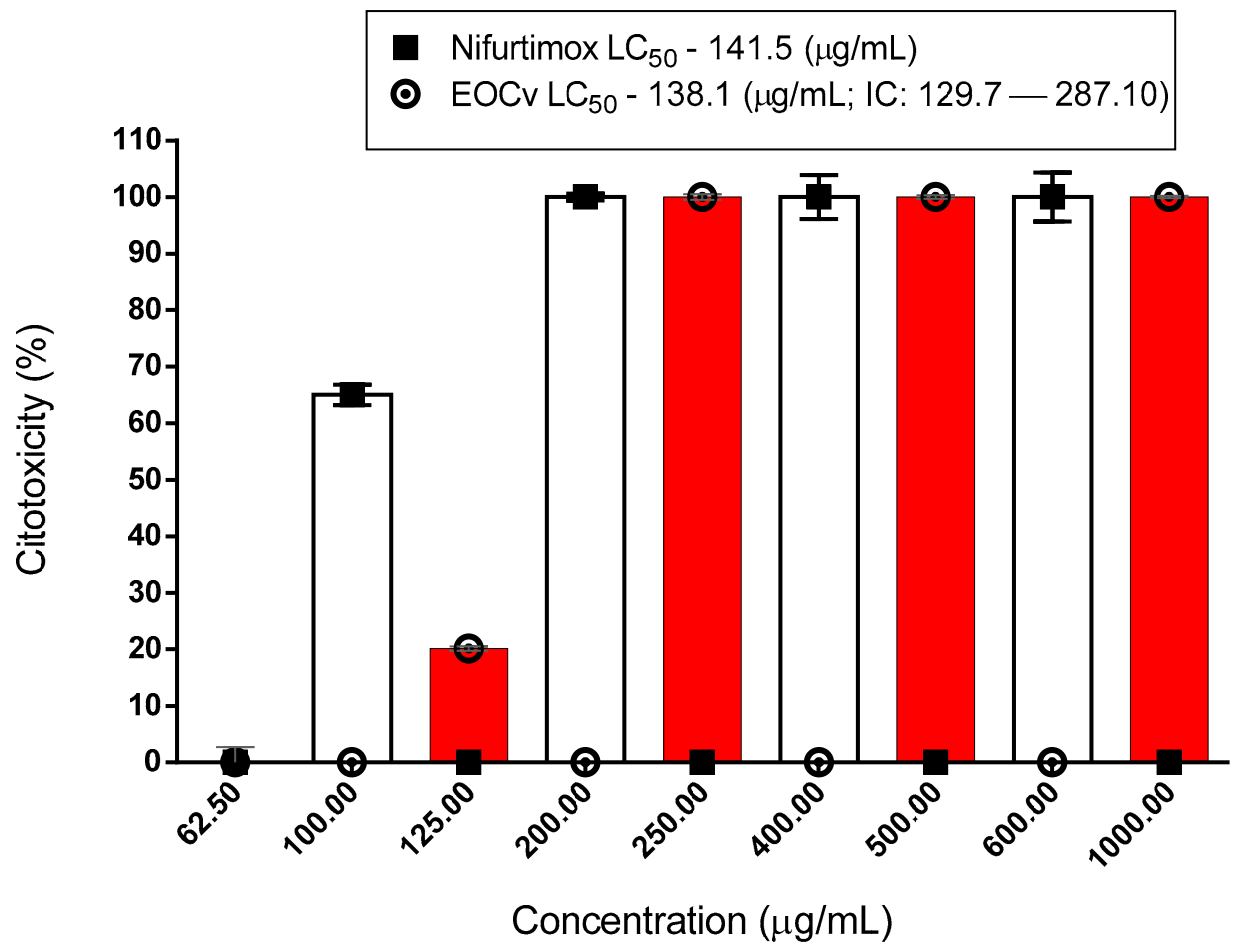

Figure 1. Cytotoxicity of C. verbenaceae essential oil. EOCv (essential oil of C. verbenaceae). 


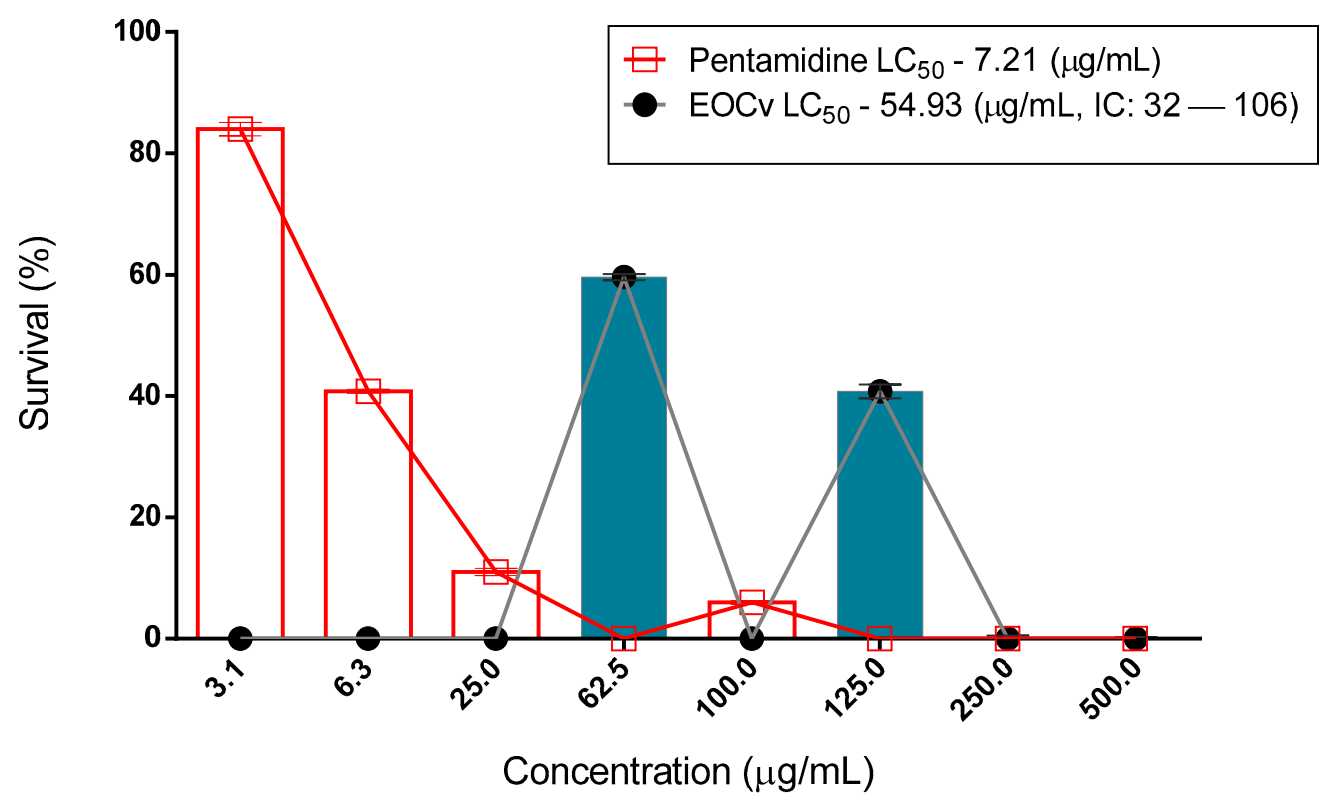

Figure 2. Survival of the promastigote L. brasiliensis treated with C. verbenaceae essential oil. LC 50 confidence interval for oil 95\% (32-106). EOCv (essential oil of C. verbenaceae).

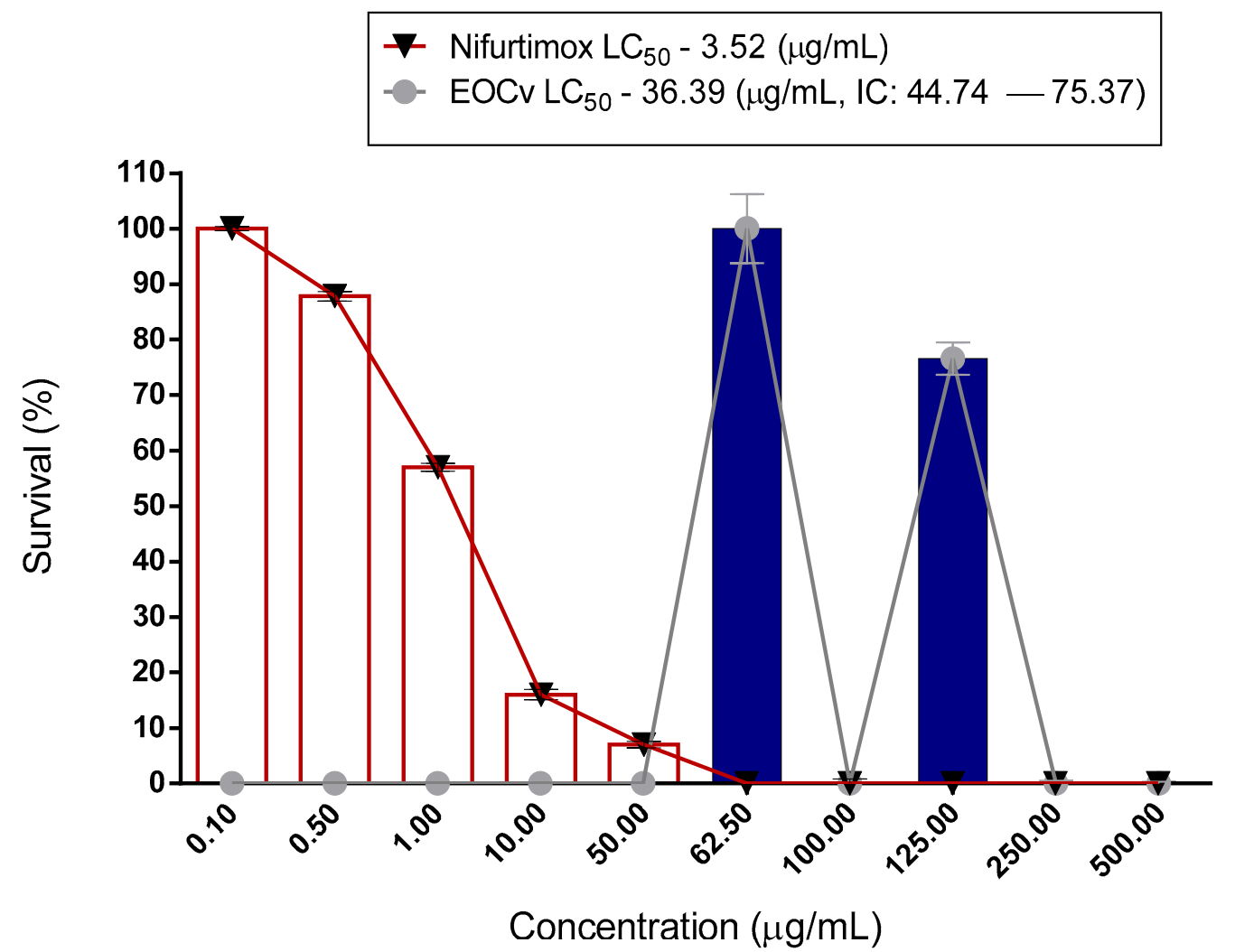

Figure 3. Survival of the epimastigote $T$. cruzi treated with $C$. verbenaceae essential oil. $\mathrm{LC}_{50}$ confidence interval for oil: 95\% (44.74-75.37). EOCv (essential oil of C. verbenaceae). 
Table 2. Cytotoxicity of C. verbenacea essential oil.

\begin{tabular}{|c|c|c|c|c|c|c|}
\hline Natural Product & $\begin{array}{l}\text { Conc. } \mu \mathrm{g} / \mathrm{mL} \\
\text { C. verbenacea }\end{array}$ & $\% \mathrm{C}$ & $\pm \%$ DS & $\begin{array}{l}\text { Conc. } \mu g / m L \\
\text { Nifurtimox }\end{array}$ & $\% \mathrm{C}$ & $\pm \%$ DS \\
\hline \multirow{10}{*}{ C. verbenacea } & 1000 & 100 & - & \multirow{3}{*}{600} & \multirow{3}{*}{100} & \multirow{3}{*}{4.3} \\
\hline & & & & & & \\
\hline & 500 & 100 & - & & & \\
\hline & & & & \multirow[t]{2}{*}{400} & \multirow[t]{2}{*}{100} & \multirow[t]{2}{*}{3.9} \\
\hline & 250 & 97.85 & 0.49 & & & \\
\hline & & & & \multirow[t]{2}{*}{200} & \multirow[t]{2}{*}{100} & \multirow[t]{2}{*}{0.6} \\
\hline & 125 & 64.21 & 0.80 & & & \\
\hline & & & & \multirow[t]{3}{*}{100} & \multirow[t]{3}{*}{65} & \multirow[t]{3}{*}{1.8} \\
\hline & 62.5 & 10.04 & 0.70 & & & \\
\hline & 31.5 & 9.04 & 0.77 & & & \\
\hline
\end{tabular}

Table 3. Survival of the promastigote L. brasiliensis treated with C. verbenaceae essential oil.

\begin{tabular}{|c|c|c|c|c|c|c|}
\hline Natural Product & $\begin{array}{l}\text { Conc. } \mu \mathrm{g} / \mathrm{mL} \\
\text { C. verbenacea }\end{array}$ & $\% \mathrm{~S}$ & $\pm \%$ DS & $\begin{array}{l}\text { Conc. } \mu \mathrm{g} / \mathrm{mL} \\
\text { Pentamidine }\end{array}$ & $\% S$ & $\pm \%$ DS \\
\hline \multirow{10}{*}{ C. verbenacea } & 1000 & 100 & - & \multirow{7}{*}{100} & \multirow{7}{*}{6.0} & \multirow{7}{*}{0.3} \\
\hline & 500 & 100 & - & & & \\
\hline & 250 & 100 & - & & & \\
\hline & 125 & 100 & - & & & \\
\hline & & & & & & \\
\hline & 62.5 & 60.87 & 2.11 & & & \\
\hline & 31.5 & 34.44 & 1.02 & & & \\
\hline & & & & 25 & 11 & 0.6 \\
\hline & & & & 6.2 & 40.8 & 0.3 \\
\hline & & & & 3.2 & 84 & 1.1 \\
\hline
\end{tabular}

Table 4. Survival of the epimastigote T. cruzi treated with C. verbenaceae essential oil.

\begin{tabular}{|c|c|c|c|c|c|c|}
\hline Natural Product & $\begin{array}{l}\text { Conc. } \mu \mathrm{g} / \mathrm{mL} \\
\text { C. verbenacea }\end{array}$ & $\% S$ & $\pm \%$ DS & $\begin{array}{l}\text { Conc. } \mathrm{g} / \mathrm{mL} \\
\text { Pentamidine }\end{array}$ & $\% S$ & $\pm \%$ DS \\
\hline \multirow{12}{*}{ C. verbenacea } & 1000 & 100 & - & \multirow{6}{*}{100} & \multirow{6}{*}{0} & \multirow{6}{*}{0.8} \\
\hline & 500 & 100 & - & & & \\
\hline & 250 & 100 & - & & & \\
\hline & 125 & 100 & - & & & \\
\hline & & & & & & \\
\hline & 62.5 & 25.11 & 1.70 & & & \\
\hline & & & & \multirow[t]{2}{*}{50} & \multirow[t]{2}{*}{7} & \multirow[t]{2}{*}{0.6} \\
\hline & 31.5 & 16.12 & 2.52 & & & \\
\hline & & & & 10 & 16 & 0.9 \\
\hline & & & & 1.0 & 57 & 0.7 \\
\hline & & & & 0.5 & 87 & 0.8 \\
\hline & & & & 0.1 & 100 & 0.4 \\
\hline
\end{tabular}

Table 2 shows that the essential oil of $C$. verbenacea is cytotoxic from a concentration of $125 \mu \mathrm{g} / \mathrm{mL}$ and at low concentrations (31.5 and $62.5 \mu \mathrm{g} / \mathrm{mL})$ it has low cytotoxicity, which may be an indication of future human consumption. The oil was lethal at these concentrations to L. brasiliensis and T. cruzi.

According to Table 3, the EOCv at a concentration of $31.5 \mu \mathrm{g} / \mathrm{mL}$, managed to be lethal at approximately $70 \%$, thus presenting a good anti-leishmanial activity.

\section{Discussion}

Vegetables have been the object of study and biological screening as an alternative for the treatment of neglected parasitic diseases [46,47]. Phytochemicals are currently being synthesized and chemically modified to ensure greater potency against these human 
pathogens [48]. In this context, the main objective of this study was to investigate the biological activities of the essential oil of $C$. verbenacea, in order to investigate its potential to inhibit the promastigote forms of Leishmania braziliensis and the epimastigote forms of Trypanosoma cruzi.

Essential oils are complex mixtures consisting of terpenoid hydrocarbons, oxygenated terpenes and sesquiterpenes. They originate from the secondary metabolism of the plant and are responsible for its characteristic aroma. Gas chromatography (GC) is the best method, due to its simplicity, speed and efficiency, both for the identification and quantification of the components of essential oils and variations in composition [49].

Within the Cordia genus, there is a certain variation in the predominance of certain components of essential oils. Some species mainly contain monoterpene hydrocarbons common to C. cylindrostachia [50], C. globosa [51]; some sesquiterpene hydrocarbons, as seen in C. verbenacea [6], C. leucocephala [52] and C. millenii [53]; a mixture of monoterpene hydrocarbons and sesquiterpenes prominent in C. trichotoma [54] and C. multispicata [55]; oils containing oxygenated monoterpenes/sesquiterpenes, such as C. myxa [56] and C. chacoensis [57], respectively; and oils with a high content of non-terpenes, present in C. sebestena [58] and C. gilletii [59].

Regarding the characteristic chemical composition of the oil in the present study, it showed similarities between most studies observed so far. The $\alpha$-pinene compound was detected in much larger quantities than the others, corroborating many other similar studies [60,61]. Caryophyllene and $\alpha$-pinene demonstrated anti-trypanocidal action against T. cruzi in the epimastigote form [62]. Still, in relation to the essential oil from C. verbenaea, some studies have been conducted relating its action to anti-trypanocidal and anti-Leishmania [63]. The class of compounds present in the greatest quantity are hydrocarbon monoterpenes, followed hydrocarbon sesquiterpenes, which is consistent with previous findings [44]. Regarding the compound Tricyclo $2.2 .1(2,6)$ heptane, this is the first report of its presence in this species.

Previous evaluations have shown that the $\mathrm{IC}_{50}$ for NCTC929 fibroblasts exposed to essential oils is generally greater than $300 \mu \mathrm{g} / \mathrm{mL}$, which indicates that the $C$. verbenacea essential oil demonstrates great viability as a leishimanicidal and trypanocidal agent in vivo $[46,64]$.

According to Ibrahim et al. [65], the fruit pulp extract of Cordia dichotoma was able to inhibit the development of the breast cancer cell line (MCF7), an effect similar to that found in the work of Ashmawy et al. [66], where the essential oil of C. africana exhibited a potent cytotoxicity against the same cell line, probably through the regulation of apoptosis. Studies on the toxicity of the C. verbenacea essential oil are practically non-existent, but it is known that the leaf extract of these species can reduce the cell viability of MCF7, presenting an $\mathrm{IC}_{50}=154 \mu \mathrm{g} / \mathrm{mL}[45]$.

The anti-leishmanicidal activity of the essential oil of $C$. verbenacea was evaluated against the promastigote form of Leishmania braziliensis. At a concentration of $125 \mu \mathrm{g} / \mathrm{mL}$, the essential oil of $C$. verbenacea exhibited $59.22 \%$ anti-promastigote activity and was more effective against L. braziliensis at a concentration of $250 \mu \mathrm{g} / \mathrm{mL}$, whose activity was $100 \%$. The essential oil of C. verbenacea showed an $\mathrm{IC}_{50}=54.93 \mu \mathrm{g} / \mathrm{mL}$, demonstrating that it was less active than the positive pentamidine control $\left(\mathrm{IC}_{50}=7.21 \mu \mathrm{g} / \mathrm{mL}\right.$ ) (Figure 2 and Table 3 ). The difference in the effectiveness of these oils against different species of Leishmania can be attributed to their distinct chemical compositions [46].

The values referring to Figure 2 and Table 3 are considered clinically relevant, as they had an effect at a concentration below $300 \mu \mathrm{g} / \mathrm{mL}$, with an $\mathrm{LC}_{50}=54.93 \mu \mathrm{g} / \mathrm{mL}$, a more promising result than usual [32]. Studies on the activity of the antipromastigote potential of this species practically do not exist, although they can be found for other species of the same genus [67]. Regarding their constituents, there are many studies that show their actions. This is true in the case of $\alpha$-pinene, which has already been shown to be an effective leishmanicidal agent due to the activity observed against the promastigote forms of L. major, as well as other hydrocarbon monoterpenes [68]. 
In relation to the other main constituent, caryophylene, according to the study by Moreira et al. [22], this compound showed activity against Leishmania amazonensis, in the promastigote and amastigote forms, with an $\mathrm{IC}_{50}$ of $49.9 \mu \mathrm{g} / \mathrm{mL}$ and $10.7 \mu \mathrm{g} / \mathrm{mL}$, respectively. In the study by Ghaderi et al. [69], it is indicated that the caryophylline oxide compound acts to inhibit oxygen consumption by Leishmania tarentolae mitochondria, causing increased oxidative stress, decreased ATP production and the consequent death of the parasite.

The potential of the C. verbenacea essential oil to inhibit the epimastigote form of Trypanosoma cruzi was pioneered in this study (Figure 3). At the same time the C. verbenacea essential oil was highly toxic (100\% lethal) to NCTC929 fibroblasts. The toxicity of the essential oil of $C$. verbenacea was possibly related to its monoterpenes ( $\alpha$-pinene) and hydrogenated sesquiterpenes (caryophyllene, tricyclo[2.2.1-(2,6)]heptane) present in the leaves of the plant species in this study. In this follow-up, we demonstrated that $(E)$ cariophylene exhibited a potent antiparasitic effect against $T$. cruzi, the result of which suggested that this compound may be the one that was responsible for the antiparasitic activity revealed in this investigation [70]. However, we cannot disregard a possible synergistic effect of the minor and major compounds of the essential oil of $C$. verbenacea.

The analysis of the result shown in Figure 3 and Table 4 revealed that the essential oil of C. verbenacea also presented values considered relevant, according to Meira et al. [71], which considered relevant $\mathrm{IC}_{50}$ values below $41.3 \mu \mathrm{g} / \mathrm{mL}$, whereas the present study was $36.39 \mu \mathrm{g} / \mathrm{mL}$. With regard to the epimastigote activity of the essential oil of this plant, this study is considered to have been pioneering. In addition, there are only studies on compounds identified after isolation. In the research carried out by Kamte et al. [72], the effect of $\alpha$-Pinene was tested against the epimastigote form of T. brucei (TC221), where an $\mathrm{LC}_{50}$ of this compound equal to $1.0 \mu \mathrm{g} / \mathrm{mL}$ was observed. As for the other compound, the main caryophyllene constituent, it has already been shown to be active against the epimastigote, amastigote and promastigote forms of T. cruzi [73].

Essential oils and their constituents can act on parasites of the genus Trypanosoma and Leishmania in several ways: (1) They affect the layers of polysaccharides, fatty acids and phospholipids in the autophagosomal structures, causing disturbances in the nuclear membrane and in the condensation of the nuclear chromatin; (2) they interrupt specific metabolic pathways for lipids and proteins or stimulate the depolarization of mitochondrial membranes, which can lead to cell necrosis or apoptosis [74]; and (3) they increase reactive oxygen species that cause DNA damage [75].

\section{Materials and Methods}

\subsection{Material Vegetal}

The leaves of $C$. verbenaceae were collected at Crato Seedling Production Bank (voucher number \# 044171).

\subsection{Obtaining Essential Oil}

The fresh leaves were cut into $1 \mathrm{~cm}^{2}$ pieces, washed and macerated with $99.9 \%$ ethanol for $72 \mathrm{~h}$ at room temperature. The essential oil was obtained by hydrodistillation in a Clevenger-type apparatus. Fresh leaves of $C$. verbenaceae were placed in a $5 \mathrm{~L}$ flask, together with $3 \mathrm{~L}$ of distilled water and heated for $2 \mathrm{~h}$. Afterward, the water/oil mixture obtained was separated, and the essential oil of $C$. verbenaceae was treated with anhydrous sodium sulfate, filtered and kept under refrigeration until the time of analysis.

\subsection{Gas Chromatography Mass Spectrometry Analysis (GC MS)}

Oil analysis was performed using a Shimadzu GC MS-QP2010 series (GC/MS system): Rtx-5MS capillary column (30 $\mathrm{m} \times 0.25 \mathrm{~mm}, 0.25 \mu \mathrm{m}$ film thickness); helium carrier gas at $1.5 \mathrm{~mL} / \mathrm{min}$; injector temperature $250{ }^{\circ} \mathrm{C}$; detector temperature $290{ }^{\circ} \mathrm{C}$; column temperature $60-180{ }^{\circ} \mathrm{C}$ at $5{ }^{\circ} \mathrm{C} / \mathrm{min}$, then $180-280{ }^{\circ} \mathrm{C}$ at $10^{\circ} \mathrm{C} / \mathrm{min}(10 \mathrm{~min})$. Scanning speed was $0.5 \mathrm{scan} / \mathrm{sec}$ from $m / z 40$ to 350. Split ratio (1:200). Injected volume: $1 \mu \mathrm{L}$ 
of $\left[25 \mu \mathrm{L}\right.$ (essential oil) $\left./ 5 \mathrm{~mL} \mathrm{CHCl}_{3}\right]$ (1:200). Solvent cut time $=2.5 \mathrm{~min}$. The mass spectrometer was operated using $70 \mathrm{eV}$ of ionization energy. Identification of individual components was based on their mass spectral fragmentation based on Mass spectral library NIST 08, retention indices, and comparison with published data.

\subsection{Antiparasitic Activity \\ Cell Lines Used}

Strains of CL-B5 parasites (clone CL-B5) were used for in vitro evaluation of the activity on T. cruzi [76]. Parasites transfected with the $\beta$-galactosidase gene of Escherichia coli (LacZ) were provided by Dr. F. Buckner through the Gorgas Memorial Institute (Panama). Epimastigotes forms cultured in LIT infusion tryptose liver at $28^{\circ} \mathrm{C}$ plus $10 \%$ fetal bovine serum (FBS), penicillin $10 \mathrm{U} / \mathrm{mL}$ and $10 \mu \mathrm{g} / \mathrm{mL}$ streptomycin at $\mathrm{pH} 7.2$, were incubated with different concentrations of essential oil $(125,62.5,31.25$ and $15.62 \mu \mathrm{g} / \mathrm{mL})$ and harvested during the exponential growth phase [77].

Antileishmanial in vitro activity was determined using promastigotes of L. braziliensis (MHOM/CW / 88/UA301) at $26^{\circ} \mathrm{C}$, grown in Schneider's insect medium, supplemented with $10 \%(v / v)$ heat-inactivated fetal calf serum, $2 \%$ normal human urine $(v / v)$ plus penicillin and streptomycin [33]. The forms were seeded and incubated with different concentrations of essential oil $(125,62.5,31.25$ and $15.62 \mathrm{~mL})$.

\subsection{Reagents}

The sodium resazurin substance was obtained from Sigma-Aldrich (St. Louis, MO, USA) and stored at $4{ }^{\circ} \mathrm{C}$ protected from light. A resazurin solution was prepared with $1 \%$ phosphate buffer, at $\mathrm{pH} 7$, and was sterilized in advance by filtration. Afterward, the chlorophenol red- $\beta$-D-galactopyranoside-CPRG (Roche, Indianapolis, IN, USA) was dissolved in a solution of Triton X-100 0.9\% (pH 7.4). Penicillin G (Ern, SA, Barcelona, Spain), streptomycin (Reig Jofre SA, Barcelona, Spain) and Dimethyl sulfoxide (DMSO) were also used.

\subsection{In Vitro Epimastigote Susceptibility Assay}

The assays were performed according to the procedures described by Vega et al. [78], with crops that had not reached the stationary phase. Epimastigotes forms were seeded at $1 \times 10^{5}$ per $\mathrm{mL}$ in $200 \mu \mathrm{L}$, in 96-well microdilution plates, which were incubated at $28{ }^{\circ} \mathrm{C}$ for $72 \mathrm{~h}$. Then, $50 \mu \mathrm{L}$ of CPRG (Chlorophenol red- $\beta$-D-galactopyranoside) solution was added to give a final concentration of $200 \mu \mathrm{M}$. The plates were incubated at $37{ }^{\circ} \mathrm{C}$ for an additional $6 \mathrm{~h}$. The absorbance reading was performed in a spectrophotometer at $595 \mathrm{~nm}$. Nifurtimox was used as reference drug. The concentrations were tested in triplicate. Each experiment was performed twice separately. The inhibition percentage (\% AE) was calculated as follows:

$$
\% \mathrm{AE}=\left[\left(\mathrm{AE} \_\mathrm{AEB}\right) /\left(\mathrm{AC} \_\mathrm{ACB}\right)\right] \times 100
$$

where AE represents the "absorbance of tested plates," AEB is the "absorbance of plates containing medium and sample," AC is the "absorbance of plates containing negative control," and ACB is the "absorbance of plates containing culture medium."

All the $\mathrm{IC}_{50}$ values were calculated by a nonlinear regression equation, using the computer program GraphPad Prism v. 6.0. The concentration of DMSO (dimethyl sulfoxide) used to enable oil solubility was not greater than $0.01 \%$.

\subsection{In Vitro Leishmanicidal Assay}

The assays were performed according to the procedures described by Mikus and Steverding [79] with some adjustments. The activity of the oil was performed in triplicate. Promastigotes forms $\left(2.5 \times 10^{5}\right.$ parasites/well $)$ were cultured in 96-well plastic plates. The samples were dissolved in dimethylsulfoxide (DMSO). Different dilutions of the compounds, up to $200 \mathrm{~mL}$ of the final volume, were added. After $48 \mathrm{~h}$ at $26{ }^{\circ} \mathrm{C}$, 
$20 \mu \mathrm{L}$ of resazurin solution was added and the oxidation-reduction was measured from 570 to $595 \mathrm{~nm}$. In each assay pentamidine was used as a control reference drug. The anti-promastigotes percentages (AP\%) were calculated. The efficacy of each compound was determined.

\subsection{Cytotoxic Assays}

In order to measure the cell viability, a colorimetric assay with resazurin was used [80]. NCTC 929 fibroblasts were seeded $\left(5 \times 10^{4}\right.$ cells/well $)$ in flat-bottom microdilution plates of 96 wells with $100 \mu \mathrm{L}$ of RPMI 1640 medium for $24 \mathrm{~h}$ at $37^{\circ} \mathrm{C}$ in $5 \% \mathrm{CO}_{2}$ for the cells to adhere to the plates. The medium was replaced by different concentrations of drugs in $200 \mu \mathrm{L}$ of medium and incubated for another $24 \mathrm{~h}$. Growth controls were included. Then, a volume of $20 \mu \mathrm{L}$ of $2 \mathrm{mM}$ solution of resazurin was added and the plates were placed in the incubator for another $3 \mathrm{~h}$ to assess cell viability. The reduction of resazurin was determined by measuring wavelength absorbance between $490 \mathrm{~nm}$ and $595 \mathrm{~nm}$ during the test's controls with media where drugs were used. Each concentration was tested three times. The cytotoxicity of each compound was estimated by calculating the percentage of cytotoxicity $(\% \mathrm{C})$.

\subsection{Statistical Analysis}

Results were expressed as mean \pm standard error of the mean (SEM) of three independent experiments carried out in triplicate. The $\mathrm{LC}_{50}$ values were calculated, by Linear Regression, using the GraphPad Prism software version 6.0.

\section{Conclusions}

As seen during this research, the essential oil of $C$. verbenaceae proved to be effective in both Leishmania and Trypanocida activities. In the trypanocidal activity, the oil of C. verbenacea in low concentration was lethal, with low cytotoxicity. The values of this oil presented here can be considered of clinical relevance, because parasitic lethality occurs at low concentrations. This result may support its future clinical application, since one of the main problems in the use of essential oils is toxicity.

Author Contributions: Conceptualization, P.S.P. and A.J.M.; methodology, M.C.V.-G.; validation, M.R. and C.C.; formal analysis, C.D.d.M.O.-T.; investigation, J.P.K.; writing-original draft preparation, A.E.D. and C.V.B.O.; writing-review and editing, P.S.P., S.R.T., L.M.B. and H.D.M.C.; visualization, A.E.D. and H.D.M.C.; project administration, A.S., P.W. and H.D.M.C. All authors have read and agreed to the published version of the manuscript.

Funding: This research received no external funding.

Institutional Review Board Statement: Not applicable.

Informed Consent Statement: Not applicable.

Data Availability Statement: Data is contained within the article.

Conflicts of Interest: The authors declare no conflict of interest.

Sample Availability: Samples of the compounds are available from the authors.

\section{References}

1. Momčilović, S.; Cantacessi, C.; Arsić-Arsenijević, V.; Otranto, D.; Otašević, S. Rapid diagnosis of parasitic diseases: Current scenario and future needs. Clin. Microbiol. Infect. 2019, 25, 290-309. [CrossRef] [PubMed]

2. Berriman, M.; Ghedin, E.; Hertz-Fowler, C.; Blandin, G.; Renauld, H.; Bartholomeu, D.C.; Lennard, N.J.; Caler, E.; Hamlin, N.E.; Haas, B.; et al. The Genome of the African Trypanosome Trypanosoma brucei. Science 2005, 309, 416-422. [CrossRef] [PubMed]

3. Jackson, A.P. Genome evolution in trypanosomatid parasites. Parasitology 2015, 142, S40-S56. [CrossRef]

4. Vacchina, P.; Lambruschi, D.A.; Uttaro, A.D. Lipoic acid metabolism in Trypanosoma cruzi as putative target for chemotherapy. Exp. Parasitol. 2018, 186, 17-23. [CrossRef]

5. Bisceglia, J.Á.; Mollo, M.C.; Gruber, N.; Orelli, L.R. Polyamines and Related Nitrogen Compounds in the Chemotherapy of Neglected Diseases Caused by Kinetoplastids. Curr. Top. Med. Chem. 2018, 18, 321-368. [CrossRef] 
6. Rodrigues, R.F.; Castro-Pinto, D.; Echevarria, A.; dos Reis, C.M.; Del Cistia, C.N.; Sant'Anna, C.M.R.; Teixeira, F.; Castro, H.; CantoCavalheiro, M.; Leon, L.; et al. Investigation of trypanothione reductase inhibitory activity by 1,3,4-thiadiazolium-2-aminide derivatives and molecular docking studies. Bioorganic Med. Chem. 2012, 20, 1760-1766. [CrossRef]

7. Friedrich, K.; Vieira, F.A.; Porrozzi, R.; Marchevsky, R.; Miekeley, N.; Grimaldi, G.; Paumgartten, F.J.R. Disposition of Antimony in Rhesus Monkeys Infected withLeishmania braziliensisand Treated with Meglumine Antimoniate. J. Toxicol. Environ. Health Part A 2011, 75, 63-75. [CrossRef]

8. Ferreira, C.D.S.; Martins, P.S.; Demicheli, C.; Brochu, C.; Ouellette, M.; Frézard, F. Thiol-induced reduction of antimony(V) into antimony(III): A comparative study with trypanothione, cysteinyl-glycine, cysteine and glutathione. BioMetals 2003, 16, 441-446. [CrossRef] [PubMed]

9. Gómez, M.A.; Navas, A.; Márquez, R.; Rojas, L.J.; Vargas, D.A.; Blanco, V.M.; Koren, R.; Zilberstein, D.; Saravia, N.G. Leishmania panamensis infection and antimonial drugs modulate expression of macrophage drug transporters and metabolizing enzymes: Impact on intracellular parasite survival. J. Antimicrob. Chemother. 2013, 69, 139-149. [CrossRef]

10. Fyfe, P.K.; Westrop, G.; Silva, A.; Coombs, G.H.; Hunter, W.N. Leishmania TDR1 structure, a unique trimeric glutathione transferase capable of deglutathionylation and antimonial prodrug activation. Proc. Natl. Acad. Sci. USA 2012, 109, 11693-11698. [CrossRef] [PubMed]

11. Moreira, V.R.; de Jesus, L.C.L.; Soares, R.-E.P.; Silva, L.D.M.; Pinto, B.A.S.; Melo, M.N.; Paes, A.M.D.A.; Pereira, S.R.F. Meglumine Antimoniate (Glucantime) Causes Oxidative Stress-Derived DNA Damage in BALB/c Mice Infected by Leishmania (Leishmania) infantum. Antimicrob. Agents Chemother. 2017, 61, e02360-16. [CrossRef] [PubMed]

12. Garg, M.; Goyal, N. MAPK1 of Leishmania donovani Modulates Antimony Susceptibility by Downregulating P-Glycoprotein Efflux Pumps. Antimicrob. Agents Chemother. 2015, 59, 3853-3863. [CrossRef] [PubMed]

13. Pandey, R.K.; Prajapati, P.; Goyal, S.; Grover, A.; Prajapati, V. Molecular Modeling and Virtual Screening Approach to Discover Potential Antileishmanial Inhibitors Against Ornithine Decarboxylase. Comb. Chem. High Throughput Screen. 2016, 19, 813-823. [CrossRef]

14. Ruiz-Santaquiteria, M.; Sánchez-Murcia, P.A.; Toro, M.A.; de Lucio, H.; Gutiérrez, K.J.; De Castro, S.; Carneiro, F.A.; Gago, F.; Jiménez-Ruiz, A.; Camarasa, M.-J.; et al. First example of peptides targeting the dimer interface of Leishmania infantum trypanothione reductase with potent in vitro antileishmanial activity \#. Eur. J. Med. Chem. 2017, 135, 49-59. [CrossRef] [PubMed]

15. Castillo, E.; Dea-Ayuela, M.A.; Bolas-Fernandez, F.; Rangel, M.; Gonzalez-Rosende, M.E. The kinetoplastid chemotherapy revisited: Current drugs, recent advances and future perspectives. Curr. Med. Chem. 2012, 17, 4027-4051. [CrossRef]

16. Yoshioka, K.; Manne-Goehler, J.; Maguire, J.H.; Reich, M.R. Access to Chagas disease treatment in the United States after the regulatory approval of benznidazole. PLoS Negl. Trop. Dis. 2020, 14, e0008398. [CrossRef]

17. Santamaria, C.; Chatelain, E.; Jackson, Y.; Miao, Q.; Ward, B.J.; Chappuis, F.; Ndao, M. Serum biomarkers predictive of cure in Chagas disease patients after nifurtimox treatment. BMC Infect. Dis. 2014, 14, 302. [CrossRef] [PubMed]

18. de Oliveira, M.T.; Branquinho, R.T.; Alessio, G.D.; Mello, C.G.C.; Nogueira-De-Paiva, N.C.; Carneiro, C.M.; Toledo, M.J.D.O.; Reis, A.B.; Martins-Filho, O.A.M.; de Lana, M. TcI, TcII and TcVI Trypanosoma cruzi samples from Chagas disease patients with distinct clinical forms and critical analysis of in vitro and in vivo behavior, response to treatment and infection evolution in murine model. Acta Trop. 2017, 167, 108-120. [CrossRef] [PubMed]

19. Jackson, Y.; Wyssa, B.; Chappuis, F. Tolerance to nifurtimox and benznidazole in adult patients with chronic Chagas' disease. J. Antimicrob. Chemother. 2020, 75, 690-696. [CrossRef] [PubMed]

20. Murcia, L.; Carrilero, B.; Viñas, P.A.; Segovia, M. Nifurtimox chemotherapy: Collateral effects in treated Trypanosoma cruzi infected patients. Rev. Espanola Quimioter. Publ. Of. Soc. Espanola Quimioter. 2012, 25, 74-75.

21. Sangenito, L.S.; Menna-Barreto, R.F.S.; D'Avila-Levy, C.M.; Branquinha, M.H.; Dos Santos, A.L.S. Repositioning of HIV Aspartyl Peptidase Inhibitors for Combating the Neglected Human Pathogen Trypanosoma cruzi. Curr. Med. Chem. 2019, 26, 6590-6613. [CrossRef]

22. Moreira, R.R.D.; Dos Santos, A.G.; Carvalho, F.A.; Perego, C.H.; Crevelin, E.J.; Crotti, A.E.M.; Cogo, J.; Cardoso, M.L.C.; Nakamura, C.V. Antileishmanial activity of Melampodium divaricatum and Casearia sylvestris essential oils on Leishmania amazonensis. Revista do Instituto de Medicina Tropical de São Paulo 2019, 61, e33. [CrossRef]

23. Ravera, M.; Moreno-Viguri, E.; Paucar, R.; Pérez-Silanes, S.; Gabano, E. Organometallic compounds in the discovery of new agents against kinetoplastid-caused diseases. Eur. J. Med. Chem. 2018, 155, 459-482. [CrossRef]

24. Oliveira, A.C.; Costa-Lima, T.C.; Souza, A.V.V.; Gonçalves-Gervásio, R.D.C.R. Essential oils activity from plants of the Brazilian Caatinga on the vegetable leafminer. Pesquisa Agropecuária Tropical 2020, 50, 50. [CrossRef]

25. Rhind, J.P. Essential Oils: A Comprehensive Handbook for Aromatic, 3rd ed.; Singing Dragon: London, UK, 2019.

26. Shokouhian, A.; Habibi, H.; Agahi, K. Allelopatic effects of some medicinal plant essential oils on plant seeds germination. J. BioSci. Biotechnol. 2016, 5, 13-17.

27. Hanif, M.A.; Nisar, S.; Khan, G.S.; Mushtaq, Z.; Zubair, M. Essential Oils. In Essential Oil Research; Springer Science and Business Media LLC: Berlin, Germany, 2019; pp. 3-17.

28. Batiha, G.E.-S.; Alkazmi, L.M.; Wasef, L.G.; Beshbishy, A.M.; Nadwa, E.H.; Rashwan, E.K. Syzygium aromaticum L. (Myrtaceae): Traditional Uses, Bioactive Chemical Constituents, Pharmacological and Toxicological Activities. Biomolecules 2020, 10, 202. [CrossRef] 
29. Hameed, I.H.; Mohammed, G.J. Phytochemistry, Antioxidant, Antibacterial Activity, and Medicinal Uses of Aromatic (Medicinal Plant Rosmarinus officinalis). In Aromatic and Medicinal Plants_Back to Nature; IntechOpen: London, UK, 2017.

30. Tiwari, G.; Patil, S.; Bondarde, P.; Khadke, S.; Gakhare, R. Antimicrobial efficacy of commercially available plant essential oils with calcium hydroxide as intracanal medicaments against Enterococcus faecalis: An in-vitro study. J. Dent. Med. Sci. 2018, 17, 19-24.

31. Larayetan, R.; Ololade, Z.S.; Ogunmola, O.O.; Ladokun, A. Phytochemical Constituents, Antioxidant, Cytotoxicity, Antimicrobial, Antitrypanosomal, and Antimalarial Potentials of the Crude Extracts of Callistemon citrinus. Evid. Based Complement. Altern. Med. 2019, 2019, 1-14. [CrossRef] [PubMed]

32. Teles, A.M.; Rosa, T.; Mouchrek, A.N.; Abreu-Silva, A.L.; Calabrese, K.D.S.; Almeida-Souza, F. Cinnamomum zeylanicum, Origanum vulgare, and Curcuma longa Essential Oils: Chemical Composition, Antimicrobial and Antileishmanial Activity. Evid. Based Complement. Altern. Med. 2019, 2019, 1-12. [CrossRef] [PubMed]

33. Baananou, S.; Bagdonaite, E.; Marongiu, B.; Piras, A.; Porcedda, S.; Falconieri, D.; Boughattas, N. Extraction of the volatile oil fromCarum carviof Tunisia and Lithuania by supercritical carbon dioxide: Chemical composition and antiulcerogenic activity. Nat. Prod. Res. 2013, 27, 2132-2136. [CrossRef] [PubMed]

34. Chansang, A.; Champakaew, D.; Junkum, A.; Amornlerdpison, D.; Chaithong, U.; Jitpakdi, A.; Riyong, D.; Wannasan, A.; Intirach, J.; Muangmoon, R.; et al. Potential of natural essential oils and cinnamaldehyde as insecticides against the dengue vector aedes aegypti (Diptera: Culicidae). Southeast Asian J. Trop. Med. Public Health 2018, 49, 6-22.

35. Hu, F.; Tu, X.-F.; Thakur, K.; Hu, F.; Li, X.-L.; Zhang, Y.-S.; Zhang, J.-G.; Wei, Z.-J. Comparison of antifungal activity of essential oils from different plants against three fungi. Food Chem. Toxicol. 2019, 134, 110821. [CrossRef] [PubMed]

36. Sugumar, S.; Ghosh, V.; Mukherjee, A.; Chandrasekaran, N. Essential Oil-Based Nanoemulsion Formation by Low- and HighEnergy Methods and Their Application in Food Preservation against Food Spoilage Microorganisms. In Essential Oils in Food Preservation, Flavor and Safety; Elsevier BV: Amsterdam, The Netherlands, 2016; pp. 93-100.

37. Pesimo, A.R. Harnessing the Solar Energy in Extracting Essential Oil for Community Based Perfumery and Aromatherapy. Open Access Libr. J. 2017, 04, 1-11. [CrossRef]

38. Aloui, Z.; Messaoud, C.; Haoues, M.; Neffati, N.; Jamoussi, I.B.; Essafi-Benkhadir, K.; Boussaid, M.; Guizani, I.; Karoui, H. AsteraceaeArtemisia campestrisandArtemisia herba-albaEssential Oils Trigger Apoptosis and Cell Cycle Arrest inLeishmania infantumPromastigotes. Evid. Based Complement. Altern. Med. 2016, 2016, 1-15. [CrossRef]

39. Saeidnia, S.; Gohari, A.R.; Haddadi, A. Biogenic trypanocidal sesquiterpenes: Lead compounds to design future trypanocidal drugs - a mini review. DARU J. Pharm. Sci. 2013, 21, 35. [CrossRef]

40. Figueira, G.-M.; Risterucci, A.-M.; Zucchi, M.I.; Cavallari, M.M.; Noyer, J.-L. Development and characterisation of microsatellite markers for Cordia verbenacea (Boraginaceae), an important medicinal species from the Brazilian coast. Conserv. Genet. 2009, 11, 1127-1129. [CrossRef]

41. Ventrella, M.C.; Marinho, C.R. Morphology and histochemistry of glandular trichomes of Cordia verbenacea DC. (Boraginaceae) leaves. Braz. J. Bot. 2008, 31, 457-467. [CrossRef]

42. Taravati, G.; Masoudian, N.; Gholamian, A. 3-Evaluation-of Medical-Metabolites-in-Boraginaceae-Family. J. Chem. Health Risks 2014, 4, 53-61.

43. Sciarrone, D.; Giuffrida, D.; Rotondo, A.; Micalizzi, G.; Zoccali, M.; Pantò, S.; Donato, P.; Rodrigues-Das-Dores, R.G.; Mondello, L. Quali-quantitative characterization of the volatile constituents in Cordia verbenacea D.C. essential oil exploiting advanced chromatographic approaches and nuclear magnetic resonance analysis. J. Chromatogr. A 2017, 1524, 246-253. [CrossRef]

44. Carvalho, V.R.D.A.; Silva, M.K.D.N.; Aguiar, J.J.S.; Bitu, V.D.C.N.; Da Costa, J.G.M.; Filho, J.R.; Coutinho, H.D.M.; Pinho, A.I.; Matias, E.F.F. Antibiotic-Modifying Activity and Chemical Profile of the Essential Oil from the Leaves ofCordia verbenaceaDC. J. Essent. Oil Bear. Plants 2017, 20, 337-345. [CrossRef]

45. Parisotto, E.B.; Michielin, E.M.; Biscaro, F.; Ferreira, S.R.S.; Filho, D.W.; Pedrosa, R.C. The antitumor activity of extracts from Cordia verbenacea D.C. obtained by supercritical fluid extraction. J. Supercrit. Fluids 2012, 61, 101-107. [CrossRef]

46. Barros, L.M.; Duarte, A.E.; Morais-Braga, M.F.B.; Waczuk, E.P.; Vega, C.; Leite, N.F.; De Menezes, I.R.A.; Coutinho, H.D.M.; Rocha, J.B.T.; Kamdem, J.P. Chemical Characterization and Trypanocidal, Leishmanicidal and Cytotoxicity Potential of Lantana camara L. (Verbenaceae) Essential Oil. Molecules 2016, 21, 209. [CrossRef] [PubMed]

47. Pereira, P.S.; Maia, A.J.; Duarte, A.E.; Oliveira-Tintino, C.D.M.; Tintino, S.R.; Barros, L.M.; Vega-Gomez, M.C.; Rolón, M.; Coronel, C.; Coutinho, H.; et al. Cytotoxic and anti-kinetoplastid potential of the essential oil of Alpinia speciosa K. Schum. Food Chem. Toxicol. 2018, 119, 387-391. [CrossRef] [PubMed]

48. Ndjonka, D.; Rapado, L.N.; Silber, A.M.; Liebau, E.; Wrenger, C. Natural Products as a Source for Treating Neglected Parasitic Diseases. Int. J. Mol. Sci. 2013, 14, 3395-3439. [CrossRef] [PubMed]

49. Chamorro, E.R.; Zambón, S.N.; Morales, W.G.; Sequeira, A.F.; Velasco, G.A. Study of the Chemical Composition of Essential Oils by Gas Chromatography. In Gas Chromatography in Plant Science, Wine Technology, Toxicology and Some Specific Applications; InTech: London, UK, 2012.

50. Fun, C.E.; Svendsen, A.B. The Essential Oil ofCordia cylindrostachyaRoem. \& Schult. Grown on Aruba. J. Essent. Oil Res. 1990, 2, 209-210. [CrossRef]

51. Miguel, M.; García-Bores, A.M.; Meraz, S.; Piedra, E.; Vila, M.A.; O Serrano, R.I.; Orozco, J.; Estrada, M.J.E.N.; A, J.C.C.I.; Alosa, I.P.N.; et al. Antimicrobial activity of essential oil of Cordia globosa. Afr. J. Pharm. Pharmacol. 2016, 10, 179-184. [CrossRef] 
52. Diniz, J.C.; Viana, F.A.; De Oliveira, O.F.; Silveira, E.R.; Pessoa, O.D.L. Chemical Composition of the Leaf Essential Oil ofCordia leucocephalaMoric from Northeast of Brazil. J. Essent. Oil Res. 2008, 20, 495-496. [CrossRef]

53. Avoseh, O.N.; Afolabi, P.O.; Lawal, O.A.; Thang, T.D.; Ascrizzi, R.; Guido, F.; Ogunwande, I.A. Essential oil of Cordia millenii from Nigeria. Am. J. Essent. Oils Nat. Prod. 2018, 6, 13-17.

54. Wille, V.K.D.; Wastowski, A.D.; Pedrazzi, C.; Sauer, M.P. COMPOSIÇÃO QUÍMICA DA MADEIRA DE Cordia trichotoma (Vell.) Arráb. ex Steud. Ciência Florestal 2017, 27, 1441. [CrossRef]

55. Das Graças, M.; Zoghbi, B.; Andrade, E.H.D.A.; Pereira, R.A.; Oliveira, J. Volatiles of theCordia multispicataCham.: A Weed Medicinal Brazilian Plant. J. Essent. Oil Res. 2010, 22, 543-545. [CrossRef]

56. Kendir, G.; Özek, G.; Özek, T.; Köroğlu, A. Leaf essential oil analysis and anatomical study of Cordia myxa from Turkey. Plant Biosyst. Int. J. Deal. all Asp. Plant Biol. 2021, 155, 204-210. [CrossRef]

57. Arze, J.B.L.; Collin, G.; Garneau, F.-X.; Jean, F.-I.; Gagnon, H. Essential Oils from Bolivia. XI. Verbenaceae: Aloysia gratissima(Gillies \& Hook.) Tronc. and Boraginaceae: Cordia chacoensisChodat. J. Essent. Oil Bear. Plants 2013, 16, 545-550. [CrossRef]

58. Adeosun, C.B.; Olaseinde, S.; Opeifa, A.; Atolani, O. Essential oil from the stem bark of Cordia sebestena scavenges free radicals. J. Acute Med. 2013, 3, 138-141. [CrossRef]

59. Bonesi, M.; Okusa, P.N.; Tundis, R.; Loizzo, M.R.; Menichini, F.; Stévigny, C.; Duez, P.; Menichini, F. Chemical Composition, Antioxidant Properties and Anti-cholinesterase Activity of Cordia gilletii (Boraginaceae) Leaves Essential Oil. Nat. Prod. Commun. 2011, 6, 253-257. [CrossRef]

60. Nizio, D.A.D.C.; Fujimoto, R.Y.; Maria, A.N.; Carneiro, P.C.F.; França, C.C.S.; Sousa, N.D.C.; Brito, F.D.A.; Sampaio, T.S.; ArrigoniBlank, M.D.F.; Blank, A.F. Essential oils of Varronia curassavica accessions have different activity against white spot disease in freshwater fish. Parasitol. Res. 2018, 117, 97-105. [CrossRef] [PubMed]

61. Marques, A.; Bonfim, F.P.G.; Dantas, W.F.C.; Puppi, R.; Marques, M. Chemical composition of essential oil from Varronia curassavica Jacq. accessions in different seasons of the year. Ind. Crop. Prod. 2019, 140, 111656. [CrossRef]

62. De Morais, M.C.; De Souza, J.V.; Filho, C.D.S.M.B.; Dolabella, S.S.; De Sousa, D.P. Trypanocidal Essential Oils: A Review. Molecules. 2020, 25, 4568. [CrossRef]

63. Le, T.B.; Beaufay, C.; Bonneau, N.; Mingeot-Leclercq, M.-P.; Quetin-Leclercq, J. Anti-protozoal activity of essential oils and their constituents against Leishmania, Plasmodium and Trypanosoma. Phytochimie 2018, 1, 1-3.

64. Díaz, J.G.; Arranz, J.C.E.; Batista, D.D.G.J.; Fidalgo, L.M.; Acosta, J.D.L.V.; De Macedo, M.B.; Cos, P. Antileishmanial Potentialities of Croton linearis Leaf Essential Oil. Nat. Prod. Commun. 2018, 13, 1801300-1934578. [CrossRef]

65. Ibrahim, A.Y.; El-Newary, S.A.; Ibrahim, G.E. Antioxidant, cytotoxicity and anti-tumor activity of Cordia dichotoma fruits accompanied with its volatile and sugar composition. Ann. Agric. Sci. 2019, 64, 29-37. [CrossRef]

66. Ashmawy, A.M.; Ayoub, I.; Eldahshan, O.A. Chemical composition, cytotoxicity and molecular profiling of Cordia africana Lam. on human breast cancer cell line. Nat. Prod. Res. 2020, 1-6. [CrossRef]

67. Mori-Yasumoto, K.; Kawano, M.; Fuchino, H.; Ooi, T.; Satake, M.; Agatsuma, Y.; Kusumi, T.; Sekita, S. Antileishmanial Compounds from Cordia fragrantissima Collected in Burma (Myanmar). J. Nat. Prod. 2008, 71, 18-21. [CrossRef] [PubMed]

68. De Andrade, P.M.; De Melo, D.C.; Alcoba, A.E.T.; Júnior, W.G.F.; Pagotti, M.C.; Magalhães, L.G.; Dos Santos, T.C.; Crotti, A.E.; Alves, C.C.; Miranda, M.L. Chemical composition and evaluation of antileishmanial and cytotoxic activities of the essential oil from leaves of Cryptocarya aschersoniana Mez. (Lauraceae Juss.). Anais da Academia Brasileira de Ciências 2018, 90, $2671-2678$. [CrossRef]

69. Ghaderi, A.; Khadem-Erfan, M.B.; Barati, M.; Ghaderi, S. Evaluation of antileishmanial effect of the plant extract of alpha-pinene (Pistacia atlantica) in vitro and in vivo. Sci. J. Kurdistan Univ. Med. Sci. 2018, 23, 32-44.

70. Martínez-Díaz, R.A.; Ibáñez-Escribano, A.; Burillo, J.; Heras, L.D.L.; Del Prado, G.; Ortuño, M.T.A.; Julio, L.F.; Gonzalez-Coloma, A. Trypanocidal, trichomonacidal and cytotoxic components of cultivated Artemisia absinthium Linnaeus (Asteraceae) essential oil. Memórias do Instituto Oswaldo Cruz 2015, 110, 693-699. [CrossRef] [PubMed]

71. Meira, C.S.; Menezes, L.; Dos Santos, T.B.; Macedo, T.S.; Fontes, J.E.N.; Costa, E.V.; Pinheiro, M.L.B.; Da Silva, T.B.; Guimarães, E.T.; Soares, M.B.P. Chemical composition and antiparasitic activity of essential oils from leaves of Guatteria friesiana and Guatteria pogonopus (Annonaceae). J. Essent. Oil Res. 2016, 29, 156-162. [CrossRef]

72. Kamte, S.L.N.; Ranjbarian, F.; Cianfaglione, K.; Sut, S.; Dall'Acqua, S.; Bruno, M.; Afshar, F.H.; Iannarelli, R.; Benelli, G.; Cappellacci, L.; et al. Identification of highly effective antitrypanosomal compounds in essential oils from the Apiaceae family. Ecotoxicol. Environ. Saf. 2018, 156, 154-165. [CrossRef]

73. Moreno, E.; Leal, S.M.; Stashenko, E.E.; García, L.T. Induction of programmed cell death in Trypanosoma cruzi by Lippia alba essential oils and their major and synergistic terpenes (citral, limonene and caryophyllene oxide). BMC Complement. Altern. Med. 2018, 18, 225. [CrossRef]

74. Machado, M.; Pires, P.; Dinis, A.; Santos-Rosa, M.; Alves, V.; Salgueiro, L.; Cavaleiro, C.; Sousa, M. Monoterpenic aldehydes as potential anti-Leishmania agents: Activity of Cymbopogon citratus and citral on L. infantum, L. tropica and L. major. Exp. Parasitol. 2012, 130, 223-231. [CrossRef]

75. Gonçalves, C.F.L.; De Freitas, M.L.; Fortunato, R.S.; Miranda-Alves, L.; Carvalho, D.; Ferreira, A.C.F. Rutin Scavenges Reactive Oxygen Species, Inactivates 5'-Adenosine Monophosphate-Activated Protein Kinase, and Increases Sodium-Iodide Symporter Expression in Thyroid PCCL3 Cells. Thyroid 2018, 28, 265-275. [CrossRef] 
76. Le-Senne, A.; Muelas-Serrano, S.; Fernández-Portillo, C.; Escario, J.A.; Gómez-Barrio, A. Biological characterization of a betagalactosidase expressing clone of Trypanosoma cruzi CL strain. Memórias do Instituto Oswaldo Cruz 2002, 97, 1101-1105. [CrossRef] [PubMed]

77. Roldos, V.; Nakayama, H.; Rolón, M.; Torres, A.M.; Trucco, F.; Torres, S.; Vega, C.; Marrero-Ponce, Y.; Heguaburu, V.; Yaluff, G Activity of a hydroxybibenzyl bryophyte constituent against Leishmania spp. and Trypanosoma cruzi: In silico, in vitro and in vivo activity studies. Eur. J. Med. Chem. 2008, 43, 1797-1807. [CrossRef]

78. Vega, C.; Escario, J.A.; Rolón, M.; Martínez-Fernández, A.R.; Gómez-Barrio, A. A new pharmacological screening assay with Trypanosoma cruzi epimastigotes expressing $\beta$-galactosidase. Parasitol. Res. 2005, 95, 296-298. [CrossRef] [PubMed]

79. Mikus, J.; Steverding, D. A simple colorimetric method to screen drug cytotoxicity against Leishmania using the dye Alamar Blue ${ }^{\circledR}$. Parasitol. Int. 2000, 48, 265-269. [CrossRef]

80. Rolon, M.; Seco, E.M.; Vega, C.; Nogal, J.J.; Escario, J.A.; Gómez-Barrio, A.; Malpartida, F. Selective activity of polyene macrolides produced by genetically modified Streptomyces on Trypanosoma cruzi. Int. J. Antimicrob. Agents 2006, 28, 104-109. [CrossRef] [PubMed] 